\title{
Molecular characterization of Coxiella burnetii isolates by infrequent restriction site-PCR and MLVA typing
} Nathalie Arricau-Bouvery*1, Yolande Hauck ${ }^{2}$, Awatef Bejaoui ${ }^{1}$, Dimitrios Frangoulidis ${ }^{3}$, Christelle C Bodier ${ }^{1}$, Armel Souriau ${ }^{1}$, Hermann Meyer ${ }^{3}$, Heinrich Neubauer ${ }^{3}$, Annie Rodolakis ${ }^{1}$ and Gilles Vergnaud ${ }^{2,4}$

\author{
Address: ${ }^{1}$ INRA, Pathologie Infectieuse et Immunologie, 37380 Nouzilly, France, ${ }^{2}$ Institute of Genetics and Microbiology, University Paris XI, \\ 91405 Orsay cedex, France, ${ }^{3}$ Bundeswehr Institute of Microbiology, Neuherbergstr. 11, 80937 Munich, Germany and ${ }^{4}$ Division d'Analyses \\ Biologiques, Centre d'Etudes du Bouchet, BP3, 91710 Vert le Petit, France \\ Email: Nathalie Arricau-Bouvery* - bouvery@tours.inra.fr; Yolande Hauck - Yolande.Hauck@igmors.u-psud.fr; \\ Awatef Bejaoui - elessa_2@yahoo.fr; Dimitrios Frangoulidis - DimitriosFrangoulidis@Bundeswehr.org; \\ Christelle C Bodier - Christelle.Bodier@tours.inra.fr; Armel Souriau - Armel.Souriau@tours.inra.fr; \\ Hermann Meyer - Hermann1Meyer@Bundeswehr.org; Heinrich Neubauer - HeinrichNeubauer@Bundeswehr.org; \\ Annie Rodolakis - Annie.Rodolakis@tours.inra.fr; Gilles Vergnaud - Gilles.Vergnaud@igmors.u-psud.fr \\ * Corresponding author
}

Published: 26 April 2006

BMC Microbiology 2006, 6:38 doi:10.1186/147I-2180-6-38

This article is available from: http://www.biomedcentral.com/I47I-2/80/6/38

(C) 2006 Arricau-Bouvery et al; licensee BioMed Central Ltd.

This is an Open Access article distributed under the terms of the Creative Commons Attribution License (http://creativecommons.org/licenses/by/2.0), which permits unrestricted use, distribution, and reproduction in any medium, provided the original work is properly cited.

\begin{abstract}
Background: Coxiella burnetii, the causative agent of $\mathrm{Q}$ fever, has a wide host range. Few epidemiological tools are available, and they are often expensive or not easily standardized across laboratories. In this work, $C$. burnetii isolates from livestock and ticks were typed using infrequent restriction site-PCR (IRS-PCR) and multiple loci variable number of tandem repeats (VNTR) analysis (MLVA).
\end{abstract}

Results: By applying IRS-PCR, I 4 C. burnetii isolates could be divided into six groups containing up to five different isolates. Clustering as deduced from MLVA typing with 17 markers provided an increased resolution with an excellent agreement to IRS-PCR, and with the plasmid type of each strain. MLVA was then applied to 28 additional $C$. burnetii isolates of different origin and 36 different genotypes were identified among the 42 isolates investigated. The clustering obtained is in agreement with published Multiple Locus Sequence Typing (MLST) data. Two panels of markers are proposed, panel I which can be confidently typed on agarose gel at a lower cost and in any laboratory setting ( 10 minisatellite markers with a repeat unit larger than 9 bp), and panel 2 which comprises 7 microsatellites and provides a higher discriminatory power.

Conclusion: Our analyses demonstrate that MLVA is a powerful and promising molecular typing tool with a high resolution and of low costs. The consistency of the results with independent methods suggests that MLVA can be applied for epidemiological studies. The resulting data can be queried on a dedicated MLVA genotyping Web service. 


\section{Background}

Q fever is caused by Coxiella burnetii, a small, Gram-negative and strict intracellular bacterium. Although Coxiella was historically considered as a member of the genus Rickettsia, gene-sequence analysis classified the Coxiella genus in the order Legionellales, family Coxiellaceae with Rickettsiella and Aquicella, and C. burnetii as the only known species of this genus [1]. Q fever is characterized by acute and chronic courses. In humans, acute $\mathrm{Q}$ fever usually presents a flu-like, self-limiting disease accompanied by myalgia and severe headache, but complications such as pneumonia or hepatitis may occur. In chronic cases, endocarditis is the main severe complication in patients with valvulopathies. Granulomatous hepatitis, vasculitis, osteomyelitis, post-Q fever fatigue syndrome (QFS) and premature delivery or abortion have also been reported $[2,3]$. In animals, $Q$ fever affects livestock and is associated with pneumonia and reproductive disorders in livestock, with abortion, stillbirth, delivery of weak and unviable newborns, placentitis, endometritis and infertility [4-6]. C. burnetii infections have been reported in a variety of wild and domestic mammals, including dogs, cats and birds. The agent has also been isolated from ticks that are vectors for spreading and maintaining C. burnetii in nature $[7,8]$. The main route of infection is inhalation of contaminated aerosol or dust containing bacteria shed by infected animals with milk, feces, placenta or vaginal secretions [6,9-14]. Oral transmission seems less common, but the consumption of contaminated raw milk and dairy-products represents a potential source of human infection [15].

Human Q fever seems to be re-emerging in various countries as the number of cases described in the literature is increasing. This increase in clinical awareness could result from renewed interest in Coxiella burnetii because of bioterrorism concerns since this highly-infectious bacterium is classified as a category B potential biological weapon. However, epidemiological markers are lacking. As a consequence, the source of human infections often remains unidentified but sheep and goats are more frequently involved in the disease cycle than other animal species. In many cases, the occurrence of human cases can be traced back to an infected flock, where the number of aborting ewes has not alerted the farmer [16].

The systematic genotyping of C. burnetii isolates would enhance our ability to identify the source of infections and consequently help reduce the number of cases in an outbreak. Although different virulence levels of infections have been observed, it is still not clear whether this is the result of a variability in bacterial virulence factors or whether it depends on the immunological background of the host. Involvement of specific virulence factors, or of particular strains, which can provoke acute or chronic forms, has not yet been demonstrated. Initially, the com 1 sequence and a certain plasmid profile were assumed to be associated with so-called acute or chronic $C$. burnetii isolates. Recent findings, however, revealed no correlation between these criteria [17-19]. Development of the acute or chronic form of $\mathrm{Q}$ fever seems to depend upon the patient's condition and immune status $[17,18]$.

Taking into account the strong similarity or event identity between QpH1 and QpDG, Coxiella strains can be divided into four groups based on the occurrence of the plasmids QpH1, QpRS, QpDV and one plasmid (without designation) derived from a chinese C. burnetii isolate [20-25]. Plasmidless C. burnetii strains carry large plasmid-homologous sequences integrated into the chromosome [26]. Analysis of the genome by techniques such as DNA-DNA hybridization or restriction fragment length polymorphism is hampered, because cultivation of the agent is wearisome. These bacteria are usually grown on cell cultures or embryonated hen's eggs.

Pulsed-field gel electrophoresis has been used for typing of C. burnetii strains [27-29], but it is sophisticated and laborious and thus not well suited for routine use. Therefore, the use of newer (usually PCR-based) DNA methods appears to be more appropriate. Infrequent restriction site-PCR (IRS-PCR) has been shown to be a robust method for the molecular characterization of bacteria such as Bartonella, Brucella, Legionella, Listeria and Salmonella [30-33]. Recently, an MLST (Multiple Loci Sequence Typing) assay was proposed for C. burnetii [34]. The assay is based upon the sequencing of 10 short intergenic regions. One hundred and seventy-three isolates of various origins could be separated into 30 different sequence types.

Multiple Loci Variable Number of Tandem Repeats (VNTR) Analysis (MLVA) is a typing method, which is gaining importance due to the availability of whole genome sequences, the often very high discriminatory power, and its very low cost, as compared to MLST for instance. MLVA typing is now considered to be the reference method for many pathogens including Mycobacterium tuberculosis [35], Bacillus anthracis [36,37], Yersinia pestis [38] and is usually applied whenever new genome sequences are released for pathogens of interest [39-43]. In a number of instances, especially in species of recent origin, the discriminatory power of MLVA is much higher than MLST [44]. Freely available resources are accessible over the internet to facilitate the setting-up of new MLVA assays $[45,46]$ or to query existing data [47]. The main aim of the present study is to examine the interest of MLVA to reveal molecular diversity among isolates of $C$. burnetii from livestock and man. A recent investigation lead to the development of a first MLVA assay for Coxiella burnetii, 
Table I: Designation and origin of Coxiella burnetii isolates

\begin{tabular}{|c|c|c|c|c|c|}
\hline Strain & Host & Source & Clinical signs & $\begin{array}{l}\text { Geographic origin } \\
\text { (departement) }\end{array}$ & Reference \\
\hline $\mathrm{CbBI}$ & Cattle & Placenta & Abortion & France (6I) & This study \\
\hline $\mathrm{CbB} 2$ & Cattle & Milk & Metritis & France (76) & This study \\
\hline $\mathrm{CbB} 3$ & Cattle & Milk & Abortion & France (63) & This study \\
\hline $\mathrm{CbB} 4$ & Cattle & Placenta & Abortion & France (6I) & This study \\
\hline CbB5 & Cattle & Milk & Abortion & France (76) & This study \\
\hline $\mathrm{CbB7}$ & Cattle & Placenta & Abortion & France $(61)$ & This study \\
\hline $\mathrm{CbBIO}$ & Cattle & Placenta & Abortion & France (29) & This study \\
\hline $\mathrm{CbCl}$ & Goat & Placenta & Abortion & France (03) & {$[51]$} \\
\hline $\mathrm{CbC2}$ & Goat & Milk & None & France (79) & This study \\
\hline $\mathrm{CbC} 4$ & Goat & Milk & - & France (04) & This study \\
\hline $\mathrm{CbC5}$ & Goat & Milk & Abortion & France (82) & This study \\
\hline $\mathrm{CbC} 6$ & Goat & Vaginal secretion & Abortion & France (04) & This study \\
\hline $\mathrm{CbC7}$ & Goat & Milk & Weak lamb & France (04) & This study \\
\hline $\mathrm{CbOl}$ & Sheep & Placenta & Abortion & France (37) & This study \\
\hline $\mathrm{CbO} 2$ & Sheep & Placenta & Abortion & France (78) & This study \\
\hline $\mathrm{CbO} 84$ & Sheep & Placenta & Abortion & France (06) & This study \\
\hline $\mathrm{CbO} 4$ & Sheep & Vaginal secretion & Weak lamb & Morocco & This study \\
\hline Scurry Q217 & Human & Liver & Hepatitis & USA & {$[52]$} \\
\hline F2 & Human & Blood & Hepatitis & France & [53] \\
\hline F4 & Human & Blood & Endocarditis & France & [53] \\
\hline RII40 & Human & Blood & Pneumonia & Russia & [54] \\
\hline Namibia & Goat & & & Namibia & [54] \\
\hline Priscilla QI77 & Goat & & Abortion & USA & [52] \\
\hline Nine Mile RSA493 & Tick & Tick & None & USA & [52] \\
\hline$J-3$ & Cattle & Milk & & Japan & [55] \\
\hline CS-Dayer & Tick & & & Slovak Republic & [54] \\
\hline Dugway 5JI08-III & Rodents & & & USA & {$[52]$} \\
\hline Z 2775/90 & Cattle & Placenta & Abortion & Germany & [54] \\
\hline Tiho I & $?$ & & & Germany & [54] \\
\hline Z 3749/92 & Cattle & & & Germany & {$[54]$} \\
\hline Z 257/94 & Cattle & & & Germany & {$[54]$} \\
\hline Z 3205/9lb & Cattle & & & Germany & [54] \\
\hline Z 335I/92 & Cattle & & & Germany & {$[54]$} \\
\hline CS-Bud & Cattle & & & Slovak Republic & {$[54]$} \\
\hline CS-R & Human & & & Italy & [54] \\
\hline CS-Florian & Human & Blood & & Slovak Republic & [54] \\
\hline Innsbruck & Goat & Placenta & Abortion & Austria & [54] \\
\hline Z 3464/92 & Goat & Placenta & Abortion & Germany & {$[54]$} \\
\hline Z 349-36/94 & Sheep & Placenta & & Germany & [54] \\
\hline Max & Sheep & Placenta & Abortion & Germany & [54] \\
\hline Z 4313/93 & Sheep & & & Germany & [54] \\
\hline Pohlheim & Sheep & & & Germany & {$[54]$} \\
\hline
\end{tabular}

using 7 markers and 16 isolates [48]. We explore here additional markers which could be used in an MLVA assay and propose two complementary panel, as recently done for Brucella MLVA typing [43]. We compare MLVA to IRSPCR analysis, and to previous MLST and MLVA reports using published data.

\section{Results and discussion}

\section{Classification of C. burnetii isolates by IRS-PCR}

Analysis of 14 C. burnetii isolates (Table 1) by four different IRS-PCR assays resulted in a total of six patterns (Table
2). The number of DNA fragments generated by IRS-PCR depends on the primers used (i.e. PsalA, PsalC, PsalG, or PsalT), and varied between 6 and 10. The size of the amplicons varied between 100 and 1,000 bp (Figure 1 and data not shown). IRS-PCR assays using PsalG and PS1 generated the highest number of DNA fragments, whereas those using PsalC/PS1 or PsalT/PS1 generated the most diverse patterns. IRS-PCR analysis was made in duplicates and little to no pattern variability between duplicate reactions was found, only minor variations in the intensity of bands. However, the number of DNA fragments was 
Table 2: Plasmid types and IRS-PCR patterns of French Coxiella burnetii isolates

\begin{tabular}{|c|c|c|c|c|c|c|}
\hline \multirow[t]{2}{*}{ Isolates } & & \multicolumn{3}{|c|}{ Plasmid type } & \multicolumn{2}{|r|}{ IRS-PCR pattern } \\
\hline & & PsalA & PsalC & PsalG & PsalT & Profile type \\
\hline $\mathrm{CbBI}$ & QpHI & $A$ & A & $A$ & $A$ & I \\
\hline CbB2 & QpHI & $A$ & $B$ & $A$ & $A$ & 2 \\
\hline CbB3 & QpHI & $A$ & $A$ & $A$ & $A$ & I \\
\hline CbB4 & QpHI & $A$ & B & $A$ & $A$ & 2 \\
\hline $\mathrm{CbB} 5$ & $\mathrm{QpHI}$ & A & A & A & $A$ & I \\
\hline CbB7 & QpHI & $A$ & $B$ & $A$ & $A$ & 2 \\
\hline $\mathrm{CbCl}$ & $\mathrm{QpHI}$ & $A$ & $A$ & $A$ & $A$ & I \\
\hline $\mathrm{CbC2}$ & QpHI & A & A & $A$ & B & 3 \\
\hline $\mathrm{CbC5}$ & QpHI & $A$ & $B$ & $A$ & B & 4 \\
\hline $\mathrm{CbC} 6$ & QpRS & A & C & A & C & 5 \\
\hline $\mathrm{CbOI}$ & QpRS & B & $D$ & B & $D$ & 6 \\
\hline $\mathrm{CbO} 2$ & QpRS & B & D & B & $D$ & 6 \\
\hline $\mathrm{CbO} 4$ & QpHI & A & A & $A$ & B & 3 \\
\hline Nine Mile RSA493 & $\mathrm{QpHI}$ & $A$ & $A$ & $A$ & $A$ & I \\
\hline
\end{tabular}

a the plasmid type was determined by plasmid-specific PCR

smaller in our study compared to others [31-33], which illustrates the interlaboratory reproducibility problems inherent with multiple loci PCR amplifications.

\section{MLVA set-up}

By analyzing available sequence data, thirty-five tandem repeats with a repeat unit longer than $6 \mathrm{bp}$, and at least four units were identified in the Microorganism Tandem Repeats Database [46]. One failed to yield a PCR product, 18 were polymorphic and 17 were kept for subsequent analyses (one was not robust enough in our hands, and did not give reproducible results). The 17 markers and corresponding primers are listed in Table 3. The loci are divided in two panels according to repeat unit length. Ten tandem repeats with repeat units equal to or longer that 9 bp which can be confidently typed on agarose gels constitute panel1. This set contains one of the seven loci previously reported by Svraka et al. [48], Cox3 (alias ms26). Seven loci have repeat units of 6 or $7 \mathrm{bp}$, six of which were previously reported [48], and the correspondence is indicated in Table 3. Cox4 (alias ms24) is reported as having a 21 base-pairs repeat unit. However, it is also seen as a 7 bp repeat unit tandem repeat in the tandem repeat database [46], and we observe allele size variations in agreement with this alternative view. Four strains are shared by the two investigations (Nine Mile, Priscilla, Florian, Dugway). Unfortunately, although Svraka et al. sequenced all the alleles they observed, the data was not made available [48]. In addition, Svraka et al. mention that they observed a discrepancy in the size estimate provided by their capillary electrophoresis equipment compared to the sequence data, and preferred to use the first estimate which is equipment-dependant, and this then makes interlaboratory comparisons more complicated.
A collection of 42 C. burnetii isolates could be differentiated by MLVA typing into 22 genotype with panel 1 alone (Figure 3 ) or 36 genotypes when using the 2 panels (Figure 4). Some isolates have an identical genotype with MLVA. For example, CbB4 and CbB7 are two isolates from French cattle with the same geographic origin. The exact source of the isolates is unknown, it could be from the same herd and explain the identical genotype.

\section{Genetic relationship of isolates}

Figure 2 shows the results of MLVA clustering analysis compared to IRS-PCR typing for 14 isolates analyzed with both methods. The two methods are in very good agreement, 6 different genotypes are identified with IRS-PCR as compared to 11 genotypes with MLVA. One discrepancy was observed for strain $\mathrm{CbB} 2$. CbB2 is identical to CbB1 and CbB5 by MLVA but shows a different IRS-PCR profile. CbB2 and CbB5 are two isolates obtained in 2001 from neighboring flocks. The affected cows showed different clinical signs (Table 1). CbB2 was isolated from cows having metritis whereas CbB5 had been isolated from cows with abortions. CbB1 originated in placenta of an aborted cow from the same area, but abortion arose before 1998 . The two abortive isolates are closely related by the two typing methods.

Figure 3 shows the result of MLVA clustering from typing 42 C. burnetii isolates with panel 1. Twenty-two genotypes are resolved. The Hunter-Gaston diversity index (HGDI) for the panel 1 assay in this collection of strains is 0.92 . Three main clusters are identified, comprising respectively 6, 8 and 8 different genotypes. Each cluster contains isolates of various geographic origins. MLVA clustering appears to correctly predict plasmid composition. Eleven 


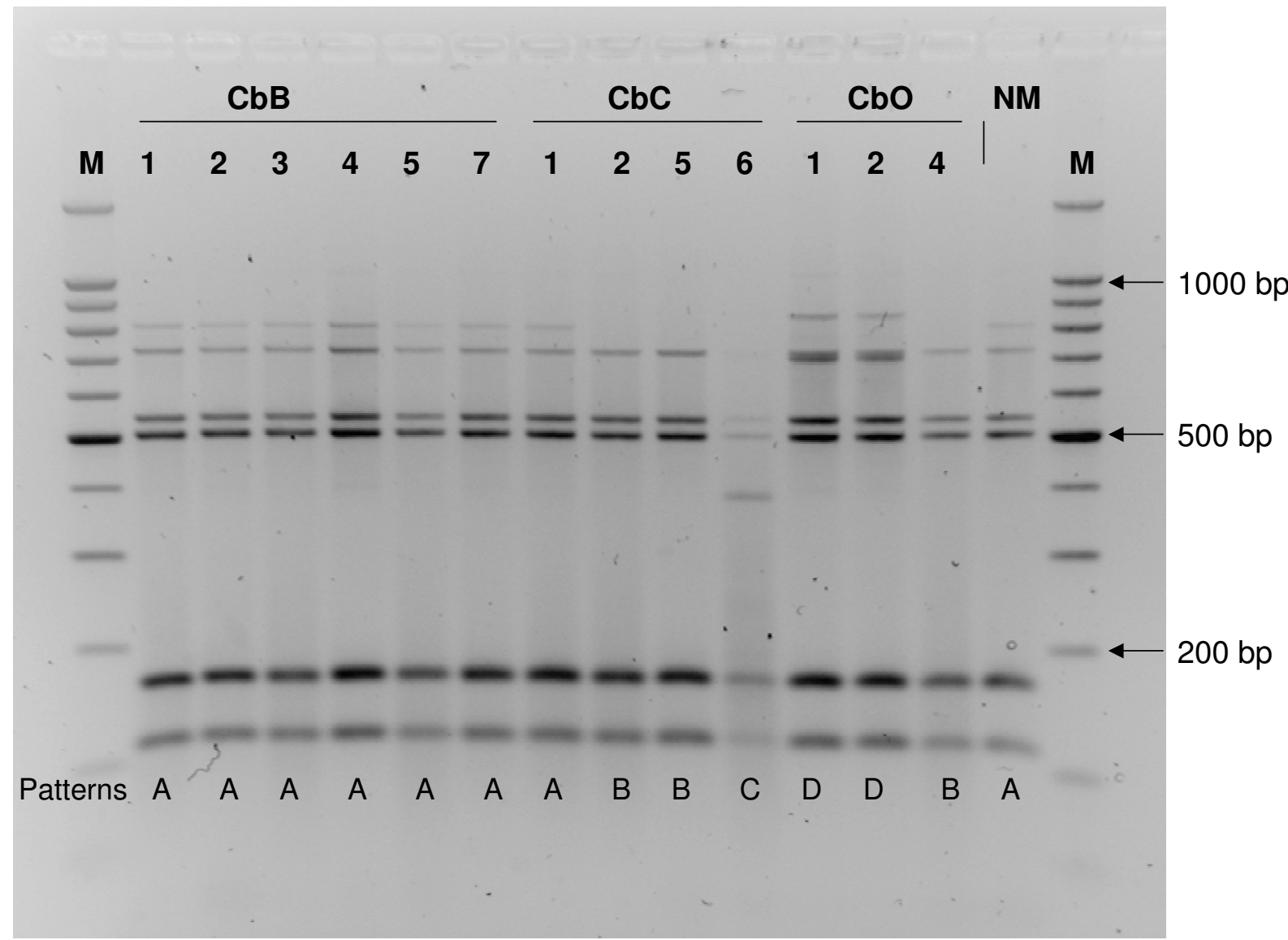

\section{Figure I}

IRS-PCR pattern of $\boldsymbol{C}$. burnetii isolates using primers PsalT et PSI. Lane M: molecular weight marker. C. burnetii strains and patterns shown are cited in Table I. NM: Nine Mile reference strain.

reference strains (Scurry Q217, R1140, Namibia, Priscilla Q177, Nine Mile RSA493, J-3, Dugway 5J108-111, Z 2775/90, CS-Florian, Z 3464/92 and Z 349-36/94) were used in our study and the recently published MLST (Multiple Loci Sequence Typing) genotyping assay [34]. In this publication, MLST typing was applied to 173 isolates of various origins. Thirty different sequence types (ST) were reported. The published sequence type (ST) is indicated in Figure 3. The isolates are grouped similarly using both methods, i.e. R1140, Namibia and Priscilla Q177 (ST2, ST30 and ST8) in a first cluster, Nine Mile RSA493, J-3, Dugway 5J108-111 and Z 2775/90 (ST16 and ST20) in a second cluster, and CS-Florian, Z 3464/92 and Z 349-36/ 94 (ST18) in a third group. Scurry Q217 (ST21) behaves like an outgroup in the MLST investigation, and is similarly poorly connected to the other groups by MLVA (see Figures 3 and 4, the different data sets associate "Scurry" to either the "red" or the "blue" clusters). The two methods are unable to discriminate the German isolates $\mathrm{Z}$
3464/92 and Z 349-36/94. Overall however, and although the methods have not been applied to the same set of isolates, the discriminatory power of MLVA panel 1 alone seems to be comparable to that achieved by the MLST assay, since 22 genotypes are distinguished here among 42 isolates, as compared to the 30 STs observed in 173 various isolates. MLVA distinguishes three ST16 isolates, but does not distinguish the ST20 strain with one of the ST16 strains (at this stage a strain error cannot be excluded). This question would eventually be solved by MLVA typing the 173 isolates previously investigated by MLST.

\section{Conclusion}

Some difficulties of the molecular epidemiology of C. burnetii are related to the fastidious growth of this bacterium. MLVA analysis does not require the isolation of the isolates. Genomic analyses of strains can be made directly with DNA purified from milk or placenta. Moreover 
Table 3: MLVA loci and properties.

\begin{tabular}{|c|c|c|c|c|c|c|c|c|c|}
\hline & Locus name & alias $^{\mathrm{a}}$ & $\begin{array}{c}\% \\
\text { matche } \\
\mathrm{s}\end{array}$ & $\begin{array}{l}\% \mathrm{G}+\mathrm{C} \\
\text { content }\end{array}$ & Primer sequence & $\begin{array}{l}\text { Estimated } \\
\text { size range } \\
\text { (bp) }\end{array}$ & $\begin{array}{c}\text { Unit } \\
\text { numbera,b }\end{array}$ & $\begin{array}{l}\text { No. of } \\
\text { alleles }^{\text {a }}\end{array}$ & HGDI \\
\hline \multirow[t]{10}{*}{$\begin{array}{l}\text { Panel I markers } \\
\text { (minisatellites, } \\
\text { repeat unit above } 9 \\
\text { base-pairs) }\end{array}$} & $\begin{array}{l}\text { Cbu0033_ms0I_I } \\
\text { 6bp_4U_198bp }\end{array}$ & & 77 & 35 & $\begin{array}{l}\text { L: } \\
\text { GGCTCATTCAATT } \\
\text { TTAGCTTCG } \\
\text { R: } \\
\text { AACGTGGGGAAG } \\
\text { TTTGTTATTT }\end{array}$ & $182-198$ & $3-4$ & 2 & 0,47 \\
\hline & $\begin{array}{l}\text { Cbu0448_ms03_I } \\
\text { 2bp_7U_229bp }\end{array}$ & & 81 & 18 & $\begin{array}{l}\text { L: } \\
\text { TTGTCGATAAATC } \\
\text { GGGAAACTT } \\
\text { R: } \\
\text { CACTGGGAAAAG } \\
\text { GAGAAAAAGA }\end{array}$ & $217-229$ & $6-7$ & 2 & 0,46 \\
\hline & $\begin{array}{l}\text { Cbu0988_ms07_I } \\
\text { 26bp_8U_III bpp }\end{array}$ & & 69 & 6 & $\begin{array}{l}\text { L: } \\
\text { CTCTTAGCCATC } \\
\text { GCTTACCACT } \\
\text { R: } \\
\text { AACGAAAATTGG } \\
\text { TTTGCATTTT }\end{array}$ & $734-1112$ & $5-8$ & 4 & 0,42 \\
\hline & $\begin{array}{l}\text { Cbul316_ms I2_I } \\
\text { 26bp_8U_1074bp }\end{array}$ & & 74 & 12 & $\begin{array}{l}\text { L: } \\
\text { GAAAATTGGTTTG } \\
\text { CGCTCTG } \\
\text { R: } \\
\text { CCTTCTCCCAAG } \\
\text { AAGTTTAGCC }\end{array}$ & $570-1200$ & $4,7-9$ & 4 & 0,67 \\
\hline & $\begin{array}{l}\text { Cbu194I_ms20_I } \\
\text { 8bp_15U_402bp }\end{array}$ & & 76 & 6 & $\begin{array}{l}\text { L: } \\
\text { CTGAAACCAGTC } \\
\text { TTCCCTCAAC } \\
\text { R: } \\
\text { CTTTATCTTGGCC } \\
\text { TCGCCCTTC }\end{array}$ & $384-528$ & $\begin{array}{c}14-15,18- \\
19,22\end{array}$ & 6 & 0,7 \\
\hline & $\begin{array}{l}\text { Cbul963_ms2I_I } \\
\text { 2bp_6U_2l0bp }\end{array}$ & & 75 & 42 & $\begin{array}{l}\text { L: } \\
\text { AGCATCTGCCTT } \\
\text { CTCAAGTTTC } \\
\text { R: } \\
\text { TGGGAGGTAGAA } \\
\text { GAAAAGATGG }\end{array}$ & $210-222$ & $5-6$ & 2 & 0,37 \\
\hline & $\begin{array}{l}\text { Cbul980_ms22_I } \\
\text { Ibp_6U_246bp }\end{array}$ & & 66 & 9 & $\begin{array}{l}\text { L: } \\
\text { GGGGTTTGAACA } \\
\text { TAGCAATACC } \\
\text { R: } \\
\text { CAATATCTCTTTC } \\
\text { TCCCGCATT }\end{array}$ & $246-257$ & $6-7$ & 2 & 0,28 \\
\hline & $\begin{array}{l}\text { Cbu083I_ms26_9 } \\
\text { bp_4U_I27bp }\end{array}$ & Cox3 & 94 & 99 & $\begin{array}{l}\text { L: } \\
\text { AGAATCAAACCT } \\
\text { GCAAAACCTT } \\
\text { R: } \\
\text { TTGATTATTTTGA } \\
\text { CTTCGCTGGT }\end{array}$ & $109-244$ & $\begin{array}{c}2,4-5,11 \\
13-14,17 \\
(2,4,13,14 \\
16,18)^{c}\end{array}$ & 6 & 0,73 \\
\hline & $\begin{array}{l}\text { Cbul35I_ms30_I } \\
\text { 8bp_6U_2I5bp }\end{array}$ & & 63 & 81 & $\begin{array}{l}\text { L: } \\
\text { ATTTCCTCGACAT } \\
\text { CAACGTCTT } \\
\text { R: } \\
\text { AGTCGATTTGGA } \\
\text { AACGGATAAA }\end{array}$ & $197-2 \mid 5$ & $5-6$ & 2 & 0,42 \\
\hline & $\begin{array}{l}\text { Cbu194I_ms36_9 } \\
\text { bp_4U_447bp }\end{array}$ & & 80 & 59 & $\begin{array}{l}\text { L: } \\
\text { GAAACCAGTCTT } \\
\text { CCCTCAACAG } \\
\text { R: } \\
\text { ATAACCGTCATC } \\
\text { GTCACCTTCT }\end{array}$ & $474-601$ & $7,15,17,21$ & 4 & 0,55 \\
\hline
\end{tabular}


Table 3: MLVA loci and properties. (Continued)

\begin{tabular}{|c|c|c|c|c|c|c|c|c|c|}
\hline \multirow[t]{7}{*}{$\begin{array}{l}\text { Panel } 2 \text { markers } \\
\text { (microsatellites, } 6 \\
\text { or } 7 \text { bp repeat } \\
\text { units) }\end{array}$} & $\begin{array}{l}\text { Cbu0197_ms23_7 } \\
\text { bp_8U_157bp }\end{array}$ & Cox6 & 90 & 51 & $\begin{array}{l}\text { L: } \\
\text { GGACAAAAATCA } \\
\text { ATAGCCCGTA } \\
\text { R:GAAAACAGAGT } \\
\text { TGTGTGGCTTC }\end{array}$ & $122-157$ & $\begin{array}{c}3,5,8(3,5- \\
6,8)^{c}\end{array}$ & 4 & 0,67 \\
\hline & $\begin{array}{l}\text { Cbu0259_ms24_7 } \\
\text { bp_27U_344bp }\end{array}$ & $\underset{d}{\operatorname{Cox} 4}$ & 94 & 46 & $\begin{array}{l}\text { L: } \\
\text { ATGAAGAAAGGA } \\
\text { TGGAGGGACT } \\
\text { R: } \\
\text { GATAGCCTGGAC } \\
\text { AGAGGACAGT }\end{array}$ & $204-344$ & $\begin{array}{c}7-13,27 \\
(6,9,12,27) \\
c\end{array}$ & 8 & 0,79 \\
\hline & $\begin{array}{l}\text { Cbu0838_ms27_6 } \\
\text { bp_4U_276bp }\end{array}$ & Cox2 & 90 & 99 & $\begin{array}{l}\text { L: } \\
\text { TTTTGAGTAAAGG } \\
\text { CAACCCAAT } \\
\text { R: } \\
\text { CAAACGTCGCAC } \\
\text { TAACTCTACG }\end{array}$ & $264-282$ & $2-5(2-4)^{c}$ & 4 & 0,73 \\
\hline & $\begin{array}{l}\text { Cbu0839_ms28_6 } \\
\text { bp_6U_276bp }\end{array}$ & Cox 5 & 94 & 83 & $\begin{array}{l}\text { L: } \\
\text { TAGCAAAGAAAT } \\
\text { GTGAGGATCG } \\
\text { R: } \\
\text { ATTGAGCGAGAG } \\
\text { AATCCGAATA }\end{array}$ & $258-288$ & $3-8(3-7)^{c}$ & 6 & 0,74 \\
\hline & $\begin{array}{l}\text { Cbul418_ms3I_7 } \\
\text { bp_5U_182bp }\end{array}$ & Cox7 & 89 & $4 I$ & $\begin{array}{l}\text { L: } \\
\text { GGGCATCTAATC } \\
\text { GAGATAATGG } \\
\text { R: } \\
\text { TTTGAGAAAATTT } \\
\text { TGGGTGCTT }\end{array}$ & $161-182$ & $\begin{array}{c}2-5 \\
\text { (idem)c }\end{array}$ & 4 & 0,51 \\
\hline & $\begin{array}{l}\text { Cbul435_ms33_7 } \\
\text { bp_9U_262bp }\end{array}$ & & 87 & 50 & $\begin{array}{l}\text { L: } \\
\text { TAGGCAGAGGAC } \\
\text { AGAGGACAGT } \\
\text { R: } \\
\text { ATGGATTTAGCCA } \\
\text { GCGATAAAA }\end{array}$ & $227-1600$ & $4,6-9$ & 6 & 0,75 \\
\hline & $\begin{array}{l}\text { Cbul47II_ms34_6 } \\
\text { bp_5U_2I0bp }\end{array}$ & Coxl & 100 & 99 & $\begin{array}{l}\text { L: } \\
\text { TGACTATCAGCG } \\
\text { ACTCGAAGAA } \\
\text { R: } \\
\text { TCGTGCGTTAGT } \\
\text { GTGCTTATCT }\end{array}$ & $192-252$ & $\begin{array}{l}2-5,7-12 \\
(2,3,5,10)^{c}\end{array}$ & 10 & 0,86 \\
\hline
\end{tabular}

a previously described loci (and corresponding data) is indicated; b an uninterrupted allele range is indicated by a '-'; c allele size range reported by [48]; d Cox4 was initially reported as a 21 bp tandem repeat [48], however we observe a 7 bp repeat unit based variation, in agreement with [46] 


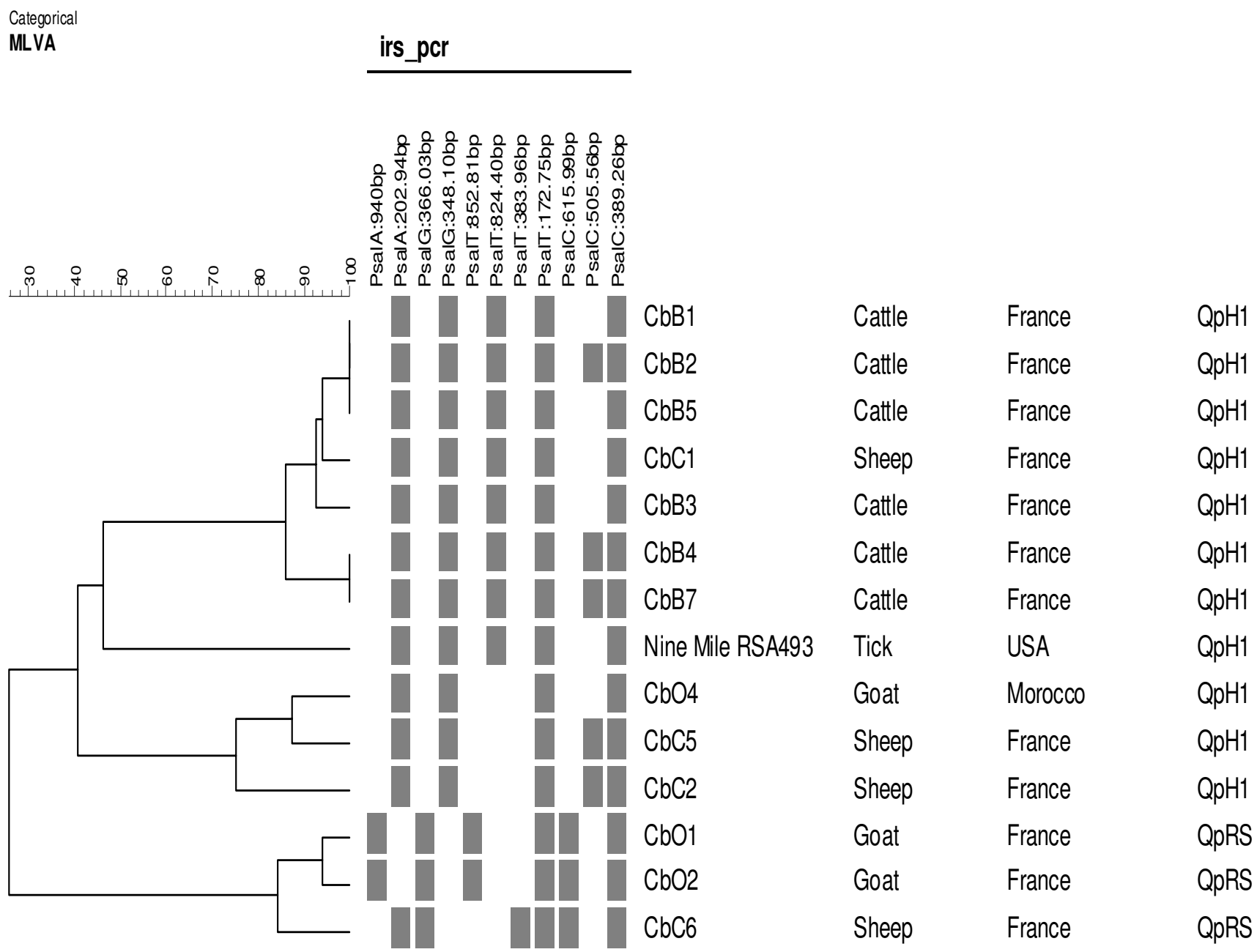

Figure 2

Comparison of MLVA clustering analysis and IRS-PCR patterns. Fourteen isolates were analysed with IRS-PCR and MLVA. A schematic view of IRS-PCR data is presented, showing informative bands.

MLVA typing can be standardized and performed at low cost, thus enabling large-scale molecular epidemiology investigations. Characterizing isolates provoking clearly defined symptoms will allow the identification of strains deserving full genome sequence determination.

Several Q-fever outbreaks have been reported in France but their origin is still unidentified [16]. The lack of epidemiological markers for C. burnetii led us to make a global analysis of the available Coxiella burnetii genome sequence in order to identify polymorphic tandem repeat loci. Using 17 such loci, we could demonstrate that IRS-PCR can divide 14 C. burnetii isolates into 6 different genotypes whereas MLVA differentiates 11 genotypes. An additional limitation of IRS-PCR is that it is essentially a patternbased assay, which is not easily amenable to interlaboratory standardization and to the making of international databases. MLVA is highly reproducible, has proved to provide efficient discriminatory tools for the molecular typing of bacteria [32], and databases are easy to set-up $[45,47]$ once a few common decisions for allele calling and marker panels have been made [44].

The discriminatory power of MLVA was evaluated using 42 C. burnetii isolates. Thirty-six genotypes are identified. Therefore, we recommend MLVA as a valuable tool for epidemiological studies. In particular, we propose to use two panels, panel 1 as a first easy screen, which can be used on agarose gels as well as more sophisticated approaches, and a panel 2, which largely corresponds to the panel previously described by Svraka et al. [48] and is best typed using a capillary electrophoresis type of equipment. The present study is an additional step towards the development of MLVA typing for Coxiella burnetii. Some of 


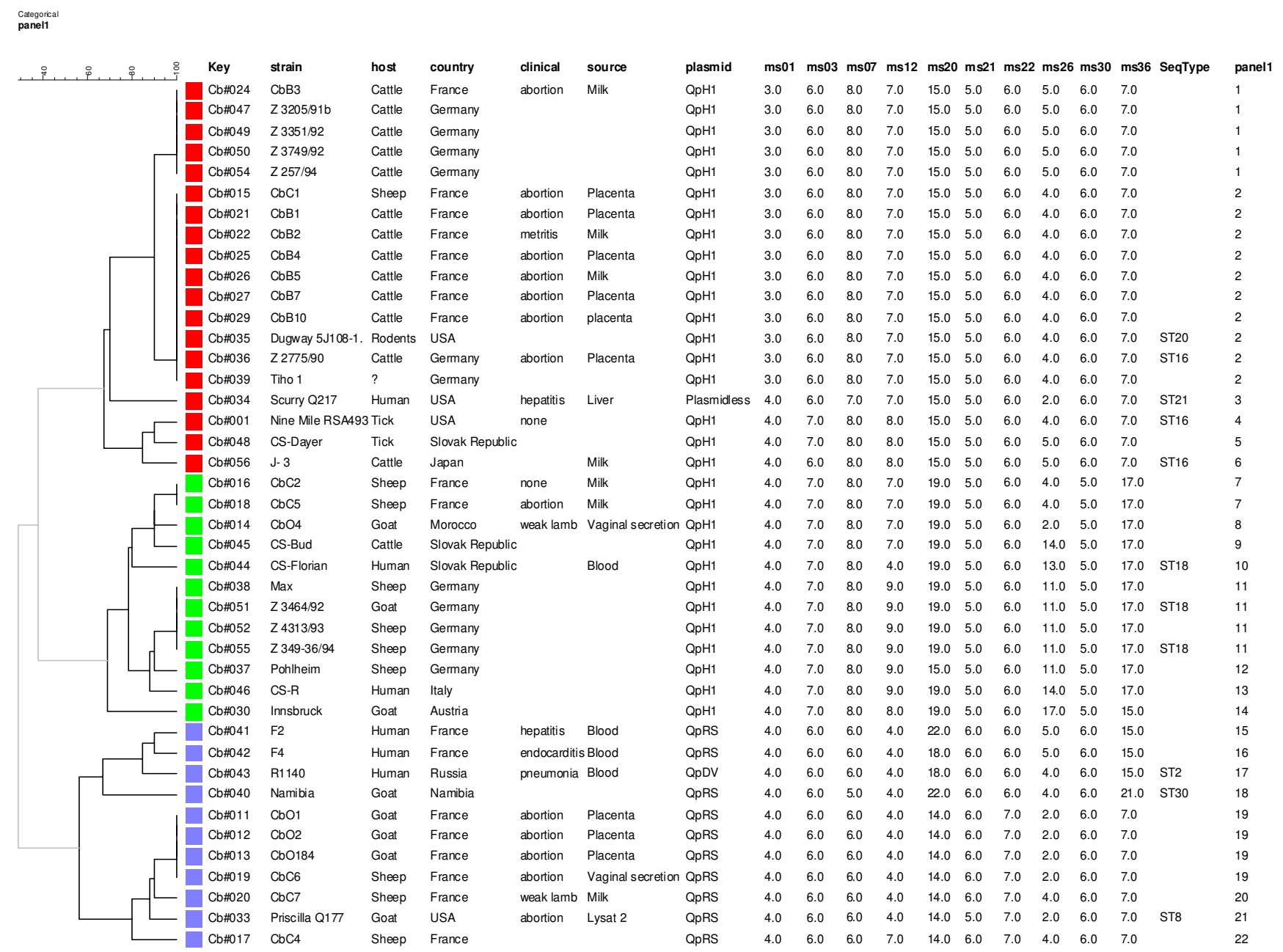

Figure 3

Dendrogram construct from MLVA Panel I data of the42 C. burnetii isolates. Key is a referencing code and refers to a DNA preparation. SeqType, sequence type (ST) as published in [34]. The genotypes have been numbered from I to 22 (panel I column) for convenience.

the markers described, in particular panel 2 markers, may eventually turn out to be too variable to be of use (discussed by [44]) when much larger collection of isolates will have been typed. Also, as soon as additional genome sequences will be available, it will be possible to search for additional polymorphic tandem repeats which might have been missed in the present investigation because they have less than 4 repeat units in the Nine Mile RS493 strain genome sequence analyzed here [45].

\section{Methods}

\section{Bacterial strains and purification}

The C. burnetii isolates used in this study are listed in Table 1. Coxiella burnetii reference strain Nine Mile was provided by AFSSA (Agence Française de Sécurité Sanitaire des Aliments), Sophia Antipolis, France. Isolates were identified as Coxiella by phenotypic and genotypic characterization.
Isolation of isolates used for IRS-PCR was performed by intraperitoneal inoculation of 3 OF1 mice ( 8 weeks old) with $0.2 \mathrm{~mL}$ of the respective animal samples (Table 1 ). The mice were killed nine days post inoculation and the spleens were sampled and reinoculated into 6-days-old, specific pathogen free, embryonated hen eggs. The infected yolk sacs (YS) of dead and viable embryos were harvested between 8 and 10 days after inoculation. C. burnetii isolates in their $3^{\text {rd }}$ passage in the chicken embryo were aliquoted and frozen at $-80^{\circ} \mathrm{C}$. Bacterial suspensions were prepared from infected YS by a series of differential sucrose density centrifugations. Prior to the purification process YS were heat inactivated $\left(80^{\circ} \mathrm{C}\right.$ for 1 hour). This was followed by sonication and by centrifugation for 45 $\min$ at $2,000 \mathrm{~g}$ in a JOUAN GR412. The supernatant (30 $\mathrm{mL}$ ) was homogenized with $20 \mathrm{~mL}$ of $20 \%$ sucrose/phosphate buffer ( $\mathrm{pH} 7.4$ ) and re-centrifuged. After removal of 


$$
\begin{aligned}
& \text { Categorical } \\
& \text { MLVA }
\end{aligned}
$$

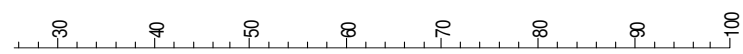

\begin{tabular}{|c|c|}
\hline CbB1 & QpH1 \\
\hline $\mathrm{CbB} 2$ & QpH1 \\
\hline CbB5 & $\mathrm{QpH} 1$ \\
\hline $\mathrm{CbC} 1$ & $\mathrm{QpH} 1$ \\
\hline CbB10 & QpH1 \\
\hline CbB3 & $\mathrm{QpH} 1$ \\
\hline CbB4 & QpH1 \\
\hline $\mathrm{CbB} 7$ & QpH1 \\
\hline Dugway 5J108-111 & QpH1 \\
\hline Z 2775/90 & $\mathrm{QpH} 1$ \\
\hline Tiho 1 & $\mathrm{QpH} 1$ \\
\hline Z 3749/92 & QpH1 \\
\hline Z 257/94 & $\mathrm{QpH} 1$ \\
\hline Z 3205/91b & $\mathrm{QpH} 1$ \\
\hline Z 3351/92 & $\mathrm{QpH} 1$ \\
\hline Nine Mile RSA493 & QpH1 \\
\hline$J-3$ & QpH1 \\
\hline CS-Dayer & QpH1 \\
\hline Scurry Q217 & Plasmidless \\
\hline $\mathrm{F} 2$ & QpRS \\
\hline $\mathrm{F} 4$ & QpRS \\
\hline R1140 & QpDV \\
\hline Namibia & QpRS \\
\hline $\mathrm{CbO} 1$ & QpRS \\
\hline $\mathrm{CbO} 2$ & QpRS \\
\hline $\mathrm{CbO} 184$ & QpRS \\
\hline $\mathrm{CbC7}$ & QpRS \\
\hline $\mathrm{CbC6}$ & QpRS \\
\hline Priscilla Q177 & QpRS \\
\hline $\mathrm{CbC} 4$ & QpRS \\
\hline CS-Florian & QpH1 \\
\hline CS-Bud & $\mathrm{QpH} 1$ \\
\hline CS-R & QpH1 \\
\hline Innsbruck & $\mathrm{QpH} 1$ \\
\hline Pohlheim & $\mathrm{QpH} 1$ \\
\hline Max & $\mathrm{QpH} 1$ \\
\hline Z 3464/92 & $\mathrm{QpH} 1$ \\
\hline Z 349-36/94 & $\mathrm{QpH} 1$ \\
\hline Z 4313/93 & QpH1 \\
\hline $\mathrm{CbO} 4$ & $\mathrm{QpH} 1$ \\
\hline $\mathrm{CbC5}$ & $\mathrm{QpH} 1$ \\
\hline $\mathrm{CbC2}$ & $\mathrm{QpH} 1$ \\
\hline
\end{tabular}

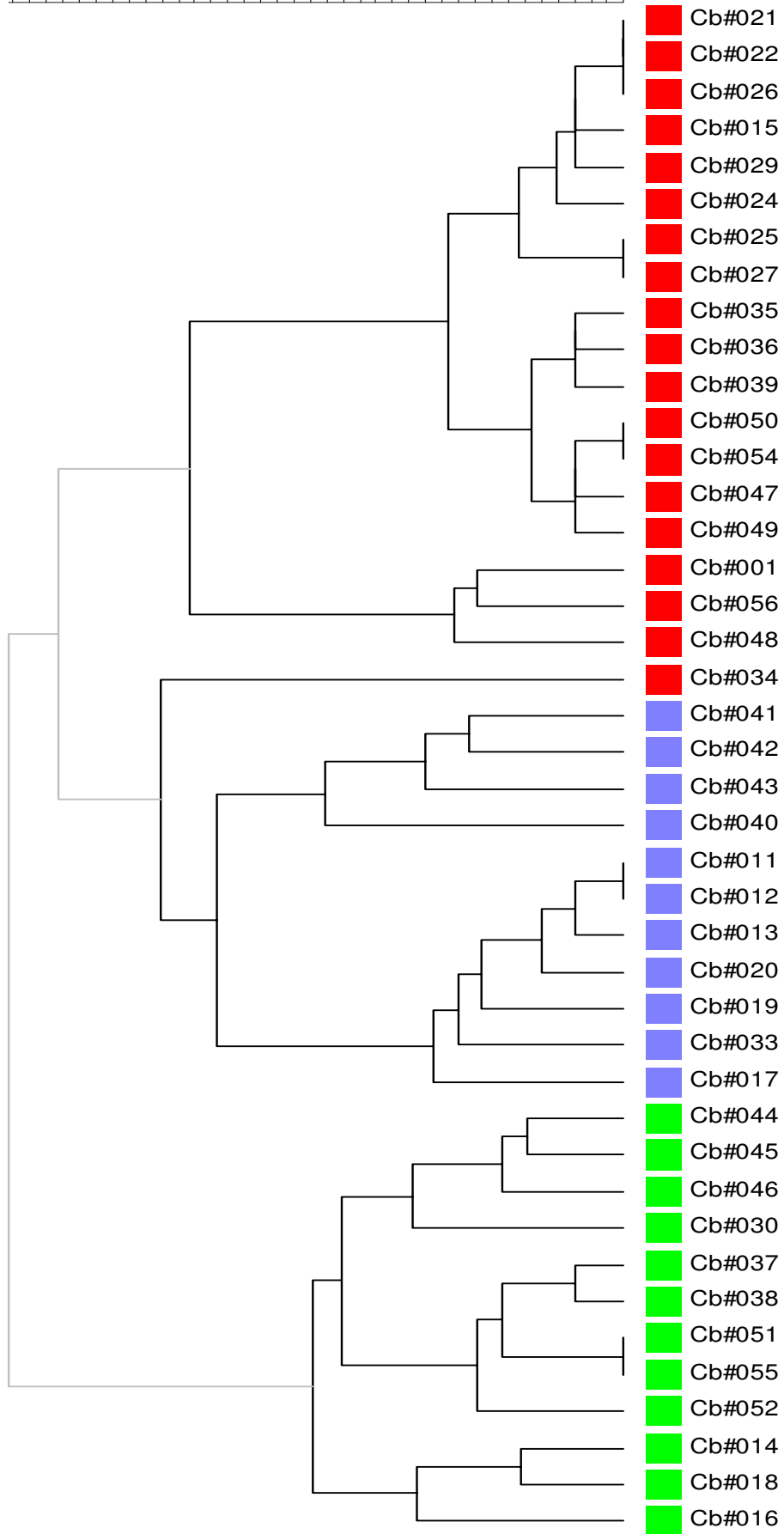

\section{Figure 4}

Dendrogram construct from MLVA Panel I+2 data ofthe $42 \mathrm{C}$. burnetii isolates. Thirty-six different genotypes are distinguished. Strains are color-coded with the same code used in Figure 3, to illustrate that the global clustering is preserved when panel 2 is added. The "Scurry" strain is the exception. 
Table 4: Oligonucleotides used for IRS-PCR and plasmid-specific PCR.

\begin{tabular}{|c|c|c|c|c|c|c|c|}
\hline \multirow[t]{2}{*}{ Designation } & \multirow[t]{2}{*}{ Sequence } & \multirow[t]{2}{*}{ Used for } & \multicolumn{3}{|c|}{ PCR conditions ( ${ }^{\circ} \mathrm{C} /$ seconds) } & \multirow{2}{*}{$\begin{array}{l}\text { No. of PCR } \\
\text { cycles }\end{array}$} & \multirow[t]{2}{*}{ Source } \\
\hline & & & Denaturation & Annealing & Extension & & \\
\hline Psl & $\begin{array}{l}5^{\prime}- \\
\text { GACTCGACT } \\
\text { CGCATGCA-3' }\end{array}$ & $\begin{array}{l}\text { Adapter I, } \\
\text { primer IRS-PCR }\end{array}$ & $94 / 30$ & $\begin{array}{c}55 / 60 \text { then } 60 / \\
30\end{array}$ & $72 / 90$ & 5 then 30 & 30 \\
\hline $\mathrm{AH} 2$ & $\begin{array}{l}\text { 5'-TGCGAGT- } \\
3^{\prime}\end{array}$ & Adapter I & & & & & 30 \\
\hline Sall & $\begin{array}{l}\text { 5'-PO4- } \\
\text { TCGATACTG } \\
\text { GCAGACTCT- } \\
3^{\prime}\end{array}$ & Adapter 2 & & & & & 30 \\
\hline$A \times 2$ & $\begin{array}{l}\text { 5'-GCCAGTA- } \\
3^{\prime}\end{array}$ & Adapter 2 & & & & & 30 \\
\hline PsalA & $\begin{array}{l}5^{\prime}- \\
\text { AGAGTCTGC } \\
\text { CAGTATCGA } \\
\text { CA-3' }\end{array}$ & Primer IRS-PCR & $94 / 30$ & $\begin{array}{c}55 / 60 \text { then } 60 / \\
30\end{array}$ & $72 / 90$ & 5 then 30 & 30 \\
\hline PsalC & $\begin{array}{l}\text { 5'- } \\
\text { AGAGTCTGC } \\
\text { CAGTATCGA } \\
\text { CC-3' }\end{array}$ & Primer IRS-PCR & $94 / 30$ & $\begin{array}{c}55 / 60 \text { then } 60 / \\
30\end{array}$ & $72 / 90$ & 5 then 30 & 30 \\
\hline PsalG & $\begin{array}{l}5^{\prime}- \\
\text { AGAGTCTGC } \\
\text { CAGTATCGA } \\
\text { CG-3' }\end{array}$ & Primer IRS-PCR & $94 / 30$ & $\begin{array}{c}55 / 60 \text { then } 60 / \\
30\end{array}$ & $72 / 90$ & 5 then 30 & 30 \\
\hline PsalT & $\begin{array}{l}5^{\prime}- \\
\text { AGAGTCTGC } \\
\text { CAGTATCGA } \\
\text { CT-3' }\end{array}$ & Primer IRS-PCR & $94 / 30$ & $\begin{array}{c}55 / 60 \text { then } 60 / \\
30\end{array}$ & $72 / 90$ & 5 then 30 & 30 \\
\hline CB5 & $\begin{array}{l}5^{\prime}- \\
\text { ATAATGAGA } \\
\text { TTAGAACAA } \\
\text { CCAAGA-3' }\end{array}$ & $\begin{array}{l}\text { Primer QpHI } \\
\text { PCR }\end{array}$ & $94 / 120$ & $53 / 60$ & $72 / 120$ & 35 & 56 \\
\hline CB6 & $\begin{array}{l}5^{\prime}- \\
\text { TCTTTCTTGT } \\
\text { TCATTTTCTG } \\
\text { AGTC-3' }\end{array}$ & $\begin{array}{l}\text { Primer QpHI } \\
\text { PCR }\end{array}$ & $94 / 120$ & $53 / 60$ & $72 / 120$ & 35 & 56 \\
\hline QpRSI & $\begin{array}{l}\text { 5'- } \\
\text { CTCGTACCC } \\
\text { AAAGACTAT } \\
\text { GAATATATC } \\
\text { C-3' }\end{array}$ & $\begin{array}{l}\text { Primer QpRS } \\
\text { PCR }\end{array}$ & $94 / 60$ & $54 / 60$ & $72 / 120$ & 36 & 56 \\
\hline QpRS2 & $\begin{array}{l}5^{\prime}- \\
\text { AACACCGAT } \\
\text { CAATGCGAC } \\
\text { TAGCCC-3' }\end{array}$ & $\begin{array}{l}\text { Primer QpRS } \\
\text { PCR }\end{array}$ & $94 / 60$ & $54 / 60$ & $72 / 120$ & 36 & 56 \\
\hline
\end{tabular}

the supernatant, the pellet was suspended in $10 \mathrm{~mL}$ Tris$\mathrm{KCl}$ and briefly sonicated again. This bacterial suspension was delicately added up to a centrifuge tube containing 5 $\mathrm{mL}$ of $60 \%$ sucrose in PBS, $5 \mathrm{~mL}$ of $50 \%$ sucrose in PBS and $10 \mathrm{~mL}$ of $40 \%$ sucrose in PBS. Centrifugation was performed at $150,000 \mathrm{~g}$ for $1 \mathrm{~h}$ at $4^{\circ} \mathrm{C}$ in a Beckman L8-55 ultracentrifuge. Coxiella bands were removed, diluted in $30 \mathrm{~mL}$ PBS and centrifuged at 150,000 g for 1 hour. The pellet was washed in $5 \mathrm{~mL}$ of PBS and centrifuged again.

\section{DNA preparation}

Preparations of purified bacteria were digested with DNAse RQ1 (Promega) at $37^{\circ} \mathrm{C}$ for $30 \mathrm{~min}$ and the reaction was stopped by addition of RQ1 stop solution. This step ensures degradation of cellular DNA. Bacteria were suspended in TNE buffer (50 mM Tris-HCl pH 8.0, 100 $\mathrm{mM} \mathrm{NaCl}, 1 \mathrm{mM}$ EDTA) and digested with proteinase $\mathrm{K}$ (Sigma) in the presence of $0.5 \%$ sodium dodecyl sulfate at $55^{\circ} \mathrm{C}$ for $1 \mathrm{~h}$. DNA was extracted with phenol and chloroform, precipitated with ethanol, dried under vacuum, and 
resuspended in TE buffer (10 mM Tris- $\mathrm{HCl} \mathrm{pH}$ 8.0, $1 \mathrm{mM}$ EDTA). The DNA concentration and purity was determined by measuring the optical density at both 260 and $280 \mathrm{~nm}$. DNA concentrations were adjusted to $0.1 \mu \mathrm{g} / \mu \mathrm{L}$ to $0.8 \mu \mathrm{g} / \mu \mathrm{L}$. DNAs were stored at $-20^{\circ} \mathrm{C}$.

\section{Plasmid specific PCR}

The plasmid composition of not previously described isolates was assayed using primers listed in Table 4. PCR amplification conditions are described in Table 4; amplimer lengths were 977 bp for QpH1 and 693 bp for QpRS.

\section{IRS-PCR}

IRS-PCR was performed as described previously [30]. The oligonucleotides that form adapters and are used for PCR amplification are listed in Table 4 . The adapters were designed to ligate specifically to the cohesive ends of the PstI and SalI restricted fragments. All oligonucleotides were purchased from Sigma-Genosys. In brief, about 0.5 $\mu \mathrm{g}$ of Coxiella DNA was digested with $10 \mathrm{U}$ of PstI (Promega) and $10 \mathrm{U}$ of SalI (Promega) for $2 \mathrm{~h} 30 \mathrm{~min}$ at $37^{\circ} \mathrm{C}$ in a volume of $15 \mu \mathrm{L}$. Ligation of the PstI $(20 \mathrm{pmol})$ and the SalI adapters $(20 \mathrm{pmol})$ was performed by adding 2.5 U of T4 DNA ligase (Promega) in a total volume of 25 $\mu \mathrm{L}$. The mixture was incubated at $16^{\circ} \mathrm{C}$ for $2 \mathrm{~h}$ and then at $60^{\circ} \mathrm{C}$ for $20 \mathrm{~min}$ to inactivate T4 DNA ligase. The sample was redigested with $5 \mathrm{U}$ of PstI and $5 \mathrm{U}$ SalI at $37^{\circ} \mathrm{C}$ for 30 min to cleave any restriction sites reformed by ligation, and then was submitted to amplification. Amplification was performed in an iCycler thermocycler (Bio-Rad, Marnes la Coquette, France) with $2.5 \mu \mathrm{L}$ of template DNA, 0.5 U of Taq DNA polymerase (Promega), deoxynucleosides triphosphates (200 $\mu \mathrm{M}$ each) (Promega) and the primers (Ps1 and either PsalA, PsalC, PsalG, or PsalT) in $1 \times$ PCR reaction buffer. Amplification consisted of an initial denaturation step at $94^{\circ} \mathrm{C}$ for $5 \mathrm{~min}$, followed by 30 cycles as indicated in Table 4 . All experiments included negative controls that were processed with the samples. The IRS-PCR reaction products were run on $2 \%(\mathrm{w} / \mathrm{v})$ agarose gels containing $0.5 \mu \mathrm{g}$ of ethidium bromide per $\mathrm{mL}$.

\section{Identification of tandem repeats}

Methods previously described [36,45,49] and accessible [46] were used to identify tandem repeats in the published genome of Coxiella burnetii RS A493 [1].

The various tandem repeat loci are designated by using the nomenclature described previously [35]. For instance Cbu0033-ms01_16bp_5U_198bp (ms01) is a tandem repeat locus at position $33 \mathrm{~Kb}$ in the C. burnetii RSA493 genome. It has a 16 bp motif and a total PCR product length of 198 bp in the RSA493 strain when using the primers set indicated in Table 3. This allele size is coded as a 5 units allele. The common laboratory name is $\mathrm{ms} 01$.

\section{VNTR amplification and genotyping}

PCR amplifications were done in a total volume of $15 \mu \mathrm{l}$ containing $1 \mathrm{ng}$ of DNA, $1 \times$ PCR reaction buffer, $1 \mathrm{U}$ of Taq DNA polymerase (Qbiogen, Illkirch, France), $200 \mu \mathrm{M}$ of each deoxynucleotide triphosphate, and $0.3 \mu \mathrm{M}$ of each flanking primer $(1 \times$ PCR buffer is $20 \mathrm{mM}$ Tris $\mathrm{pH} 8.75,10$ $\mathrm{mM} \mathrm{KCl}, 10 \mathrm{mM}(\mathrm{NH} 4)_{2} \mathrm{SO}_{4}, 2 \mathrm{mM} \mathrm{MgSO}_{4}, 1.5 \mathrm{mM}$ $\mathrm{MgCl}_{2}, 0.1 \%$ Triton X-100, $1 \mathrm{M}$ Betaine). Amplifications were performed in a MJ Research PTC200 thermocycler. Initial denaturation at $94^{\circ} \mathrm{C}$ for 5 minutes was followed by 30 cycles consisting of denaturation at $94^{\circ} \mathrm{C}$ for $30 \mathrm{~s}$, primer annealing at $60^{\circ} \mathrm{C}$ for $30 \mathrm{~s}$, and elongation at $70^{\circ} \mathrm{C}$ for $1 \mathrm{~min}$. The final extension step was at $72^{\circ} \mathrm{C}$ for $5 \mathrm{~min}$. A different elongation time was used for $\mathrm{ms} 07$, ms12 and ms33 (the extension time was 150 seconds at $70^{\circ} \mathrm{C}$ ). Five microliters of amplification product were loaded on a $2 \%$ standard agarose gel for panel 1 markers and on a 3\% standard agarose gel (Qbiogen, Illkirch, France) for tandem repeats with a 6 or 7 bp repeat unit (panel 2). Gels were stained with ethidium bromide, visualized under UV light, and photographed (Vilber Lourmat, Marnes-la-Vallée, France). The size markers used were a 100-bp or 20-bp ladder (Bio-Rad, Marnes la Coquette, France) according to the tandem repeat unit length. Gel images were managed using the Bionumerics software package (version 4.5, Applied-Maths, Belgium).

\section{Data analysis}

IRS-PCR patterns were analysed using an Alpha Imager Gel Analysis System Fluorchem version 2.00 (Alpha Innotech Corporation) following the manufacturer's recommendations. VNTR alleles size estimates were converted to number of units within a character dataset. Clustering analyses used the categorical coefficient and UPGMA (Unweighted Pair Group Method using Arithmetic averages). The use of the categorical parameter implies that the character states are considered unordered. The same weight is given to a large or a small number of differences in the number of repeats at each locus. Simpson's diversity index was used as suggested by [50].

\section{Authors' contributions}

NAB participated in the design of the study, culture of isolates and molecular genetic studies. YH evaluated tandem repeat markers and carried out all the MLVA molecular genetic studies. GV analyzed the typing data. AB participated in PCR amplification of plasmids. DF and HM selected strains. CCB participated in IRS-PCR molecular genetic studies. AS participated in isolation and culture of isolates, and purification of bacteria. AR participated in search and obtaining grant. NAB, DF, HM and GV drafted the manuscript. All authors read and approved the final manuscript.

\section{Acknowledgements}


This work was supported by the "Département Santé Animale" for INRA (Institut National de Recherche Agronomique), by the French DGA (Délégation Générale pour l'Armement) and the European bio-defense project CEPAI 3. I 4 as part of efforts to control dangerous pathogens by developing surveillance tools.

We like to thank G. Baljer (Gießen, Germany) for providing Coxiella DNA and strains.

\section{References}

I. Seshadri R, Paulsen IT, Eisen JA, TD R, Nelson KE, Nelson WC, Ward NL, Tettelin H, Davidsen TM, Beanan MJ, Deboy RT, Daugherty SC, Brinkac LM, Madupu R, Dodson RJ, Khouri HM, Lee KH, Carty HA Scanlan D, Heinzen RA, Thompson HA, Samuel JE, Fraser CM, Heidelberg JF: Complete genome sequence of the Q-fever pathogen Coxiella burnetii. Proc Natl Acad Sci USA 2003, I 00:5455-5460.

2. Hatchette TF, Hayes M, Merry H, Schlech WF, Marrie T]: The effect of $C$. burnetii infection on the quality of life of patients following an outbreak of $\mathbf{Q}$ fever. Epidemiol Infect 2003, I 30:49|-495.

3. Raoult D, Tissot-Dupont $H$, Foucault $C$, Gouvernet J, Fournier PE Bernit E, Stein A, Nesri M, Harle JR, Weiller PJ: Q fever I 985-I998. Clinical and epidemiologic features of $\mathrm{I}, 383$ infections. Medicine 2000, 79: 109-123.

4. Bildfell RJ, Thomson GW, Haines DM, McEwen BJ, Smart N: Coxiella burnetii infection is associated with placentitis in cases of bovine abortion. J Vet Diagn Invest 2000, I 2:419-425.

5. Moeller RB: Causes of caprine abortion: diagnostic assessment of 2II cases (199I-1998). J Vet Diagn Invest 200I, I 3:265-270

6. To H, Htwe KK, Yamasaki N, Zhang GQ, Ogawa M, Yamaguchi T, Fukushi H, Hirai K: Isolation of Coxiella burnetii from dairy cattle and ticks, and some characterization of the isolates in Japan. Microbiol Immunol 1995, 39:663-67I.

7. Babudieri B: $\mathbf{Q}$ fever: a zoonosis. Adv Vet Sci 1959, 5:8I-154.

8. Lang GH: Coxiellosis (Q fever) in animals CRC press, Boca Raton; 1990.

9. Martinov SP, Neikov P, Popov GV: Experimental $\mathbf{Q}$ fever in sheep. Eur J Epidemiol 1989, 5:428-43I.

10. Palmer NC, Kierstead M, Key DW, Williams JC, Peacock MG, Vellend $\mathrm{H}$ : Placentitis and abortion in goats and sheep in Ontario causedby Coxiella burnetii. Can Vet J 1983, 24:60-61.

II. Stein A, Raoult D: Pigeon pneumonia in provence: a bird-borne Q fever outbreak. Clin Infect Dis 1999, 29:617-620.

12. Stoker MGP, Brown RD, Kett FJL, Collings PC, Marmion BP: $\mathbf{Q}$ fever in Britain. Isolation of Rickettsia burneti from placenta and wool of sheep in an endemic area. J Hyg 1955, 53:313.

13. Tissot-Dupont H, Torres S, Nezri M, Raoult D: Hyperendemic focus of $\mathbf{Q}$ fever related to sheep and wind. Am J Epidemiol 1999 , I 50:67-74.

14. Welsh HH, Lennette EH, Abinanti FR, Winn JF: Airborne transmission of $\mathbf{Q}$ fever: the role of parturition in generation of infective aerosol. Ann New York Acad SCI 1957, 70:528-540.

15. Fishbein DB, Raoult D: A cluster of Coxiella burnetii infections associated with exposure to vaccinated goats and their unpasteurized dairy products. Am J Trop Med Hyg 1992, 47:35-40.

16. Berri M, Rousset E, Champion JL, Arricau-Bouvery N, Russo P, Pepin $M$, Rodolakis $A$ : Ovine manure used as a garden fertiliser is suspected to be a contamination source of two human $\mathbf{Q}$ fever cases. Vet record 2003, I 53:269-270.

17. Stein A, Raoult D: Lack of pathotype specific gene inhuman Coxiella burnetii isolates. Microb Pathog 1993, 15:177-185.

18. Thiele $D$, Willems $\mathrm{H}$ : Is plasmid based differentiation of Coxiella burnetii in 'acute' and 'chronic' isolates still valid? Eur J Epidemiol 1994, 10:427-434.

19. Zhang GQ, To H, Yamaguchi T, Fukushi H, Hirai K: Differentiation of Coxiella burnetii by sequence analysis of the gene (com I) encoding a $27-k D a$ outer membrane protein. Microbiol Immunol 1997, 4 I:87|-877.

20. Hendrix LR, Samuel JE, Mallavia LP: Differentiation of Coxiella burnetii isolates by analysis of restriction-endonucleasedigested DNA separated by SDS-PAGE. J Gen Microbiol I991, 137:269-276.
21. Lautenschlager S, Willems H, Jäger C, Baljer G: Sequencing and characterization of the cryptic plasmid QpRS from Coxiella burnetii. Plasmid 2000, 44:85-88.

22. Ning Z, Yu SR, Quan YG, Xue Z: Molecular characterization of cloned variants of Coxiella burnetii isolated in China. Acta Virol 1992, 36:173-183.

23. Thiele $D$, Willems $H$, Haas $M$, Krauss $H$ : Analysis of the entire nucleotide sequence of the cryptic plasmid QpHI from Coxiella burnetti. Eur J Epidemiol I994, I 0:4 I 3-420.

24. Valkova D, Kazar J: A new plasmid (QpDV) common to Coxiella burnetii isolates associated with acute and chronic $Q$ fever. FEMS Microbiol Lett 1995, I 25:275-280.

25. Jäger C, Lautenschlager S, Willems H, Baljer G: Coxiella burnetii plasmid types QpDG and QpH I are closely related and likely identical. Vet Microbiol 2002, 89:161-166.

26. Willems $H$, Ritter $M$, Jäger $C$, Thiele D: Plasmid-homologous sequences in the chromosome of plasmidless Coxiella burnetii Scurry Q2 I 7. J Bacteriol 1997, I 79:3293-3297.

27. Heinzen R, Stiegler GL, Whiting LL, Schmitt SA, Malavia LP, Frazier ME: Use of pulse field gel electrophoresis to differentiate Coxiella burnetii strains. Ann NY Acad Sci 1990, 590:504-5I3.

28. Jäger C, Willems H, Thiele D, Baljer G: Molecular characterization of Coxiella burnetii isolates. Epidmiol Infect 1998, I 20:157-164

29. Thiele D, Willems H, Kopf G, Krauss H: Polymorphism in DNA restriction patterns of Coxiella burnetii isolates investigated by pulse field gel electrophoresis and image analysis. Eur J Epidemiol 1993, 9:419-425.

30. Cloeckaert A, Grayon M, Grepinet O, Boumedine KS: Classification of Brucella strains isolated from marine mammals by infrequent restriction site-PCR and development of specific PCR identification tests. Microbes Infect 2003, 5:593-602.

31. Franciosa G, Tartaro S, Wedell-Neergaard C, Aureli P: Characterization of Listeria monocytogenes strains involved in invasive and noninvasive listeriosis outbreaks by PCR-based fingerprinting techniques. Appl Environ Microbiol 2001, 67: I793-1799.

32. Garaizar J, Lopez-Molina N, Laconcha I, Lau Baggesen D, Rementeria A, Vivanco A, Audicana A, Perales I: Suitability of PCR fingerprinting, infrequent-restriction-site $P C R$, and pulsed-field gel electrophoresis, combined with computerized gel analysis, in library typing of Salmonella enterica serovar Enteritidis. Appl Environ Microbiol 2000, 66:5273-528I.

33. Handley SA, Regnery RL: Differentiation of pathogenic Bartonella species by infrequent restriction site PCR. J Clin Microbiol 2000, 38:3010-3015.

34. Glazunova O, Roux V, Freylikman O, Sekeyova Z, Fournous G, Tyczka J, Tokarevich N, Kovacava E, Marrie TJ, Raoult D: Coxiella burnetii genotyping. Emerg Infect Dis 2005, I I: I2 I I- I 2 I7.

35. Le Flèche $P$, Fabre $M$, Denoeud $F$, Koeck JL, Vergnaud G: High resolution, on-line identification of strains from the Mycobacterium tuberculosis complex based on tandem repeat typing. BMC Microbiol 2002, 2:37.

36. Le Flèche $P$, Hauck $Y$, Onteniente $L$, Prieur A, Denoeud F, Ramisse $V$ Sylvestre $P$, Benson $G$, Ramisse F, Vergnaud $G$ : A tandem repeats database for bacterial genomes: application to the genotyping of Yersinia pestis and Bacillus anthracis. BMC Microbiol 200I, I:2.

37. Lista L, Faggioni G, Valjevac S, Ciammaruconi A, Vaissaire J, le Doujet C, Gorge O, De Santis R, Carattoli A, Ciervo A, Fasanella A, Orsini F, D'Amelio R, Pourcel C, Cassone A, Vergnaud G: Genotyping of Bacillus anthracis strains based on automated capillary 25 . loci Multiple Locus Variable-Number Tandem Repeats Analysis. BMC Microbiology 2006, 6:33.

38. Pourcel C, Andre-Mazeaud F, Neubauer H, Ramisse F, Vergnaud G: Tandem repeats analysis for the high resolution phylogenetic analysis of Yersinia pestis. BMC Microbiol 2004, 4:22.

39. Pourcel C, Vidgop Y, Ramisse F, Vergnaud G, Tram C: Characterization of a Tandem Repeat Polymorphism in Legionella pneumophila and Its Use for Genotyping. J Clin Microbiol 2003. 41:|8|9-|826.

40. Onteniente L, Brisse S, Tassios PT, Vergnaud G: Evaluation of the polymorphisms associated with tandem repeats for Pseudomonas aeruginosa strain typing. J Clin Microbiol 2003, 41:4991 -4997.

41. Ramisse V, Houssu P, Hernandez E, Denoeud F, Hilaire V, Lisanti O, Ramisse F, Cavallo JD, Vergnaud G: Variable number of tandem- 
repeats in Salmonella enterica subsp. enterica fortyping purposes. J Clin Microbiol 2004, 42:5722-5730.

42. Koeck JL, Njanpop-Lafourcade BM, Cade S, Varon E, Sangare L, Valjevac S, Vergnaud G, Pourcel C: Evaluation and selection of tandem repeat loci for Streptococcus pneumoniae MLVA strain typing. BMC Microbiol 2005, 5:66.

43. Le Fleche P, Jacques I, Grayon M, AI Dahouk S, Bouchon P, Denoeud F, Nockler K, Neubauer H, Guilloteau LA, Vergnaud G: Evaluation and selection of tandem repeat loci for a Brucella MLVA typing assay. BMC Microbiol 2006, 6:9.

44. Vergnaud G, Pourcel C: Multiple Locus VNTR (Variable Number of Tandem Repeat) Analysis (MLVA). In Molecular Identification, Systematics and Population Structure of Prokaryotes Edited by: Stackebrandt E. Springer-Verlag; 2006:83-104.

45. Denoeud F, Vergnaud G: Identification of polymorphic tandem repeats by direct comparison of genome sequence from different bacterial strains: a Web-based ressource. $B M C$ Bioinformatics 2004, 5:4.

46. The Microorganisms Tandem Repeats Database [http://min isatellites.u-psud.fr]

47. The MLVA Web Service [http://bacterial-genotyping.igmors.upsud.fr]

48. Svraka S, Toman R, Skultety L, Slaba K, Homan WL: Establishment of a genotyping scheme for Coxiella burnetii. FEMS Microbiol Lett 2006, 254:268-274.

49. Vergnaud G, Denoeud F: Minisatellites: Mutability and Genome Architecture. Genome Res 2000, 10:899-907.

50. Hunter PR, Gaston MA: Numerical index of the discriminatory ability of typing systems: an application of Simpson's index of diversity. J Clin Microbiol 1988, 26:2465-2466.

51. Arricau Bouvery N, Souriau A, Lechopier P, Rodolakis A: Experimental Coxiella burnetii infection in pregnant goats: excretion routes. Vet Res 2003, 34:423-433.

52. Samuel JE, Frazier ME, Mallavia LP: Correlation of plasmid type and disease caused by Coxiella burnetii. Infect Immun 1985, 49:775-779.

53. Stein A, Raoult D: Detection of Coxiella burnetti by DNA amplification using polymerase chain reaction. J Clin Microbiol 1992, 30:2462-2466.

54. Willems $H$, Thiele $D$, Krauss $H$ : Plasmid based differentiation and detection of Coxiella burnetii in clinical samples. EurJ Epidemiol 1993, 9:41।-418.

55. Nguyen SV, Hirai K: Differentiation of Coxiella burnetii isolates by sequence determination and PCR-restriction fragment length polymorphism analysis of isocitrate dehydrogenase gene. FEMS Microbiol Lett 1999, 180:249-254.

56. Zhang GQ, Hotta A, Mizutani M, Ho T, Yamaguchi T, Fukushi H, Hirai $\mathrm{K}$ : Direct identification of Coxiella burnetii plasmids in human sera by nested PCR. J Clin Microbiol 1998, 36:2210-22I3.
Publish with Bio Med Central and every scientist can read your work free of charge

"BioMed Central will be the most significant development for disseminating the results of biomedical research in our lifetime. "

Sir Paul Nurse, Cancer Research UK

Your research papers will be:

- available free of charge to the entire biomedical community

- peer reviewed and published immediately upon acceptance

- cited in PubMed and archived on PubMed Central

- yours - you keep the copyright
BioMedcentral 